\title{
DAMPAK MARAKNYA KEKERASAN ANTAR PELAJAR TERHADAP MOTIVASI BELAJAR
}

\author{
Akfa Syaufika Rahman, Siti Nurjannah, Intan Rahma Utami. \\ afkasyaufika@gmail.com \\ Mahasiswa Fakultas Teknik
}

\begin{abstract}
ABSTRAK
Seperti kita ketahui bersama bahwa maraknya aksi kekerasan antar pelajar saat ini begitu sering kita dengar dan kita saksikan di masyarakat. Fenomena ini begitu menggejala dan membuat miris dunia pendidikan kita. Tak pelak jika orang tua dan guru sebagai pendidik sangat mengkhawatirkan kondisi ini. Kekerasan antar pelajar dalam berbagai bentuknya, seperti buliying, kekerasan fisik, kekerasan psikologis terhadap anak dan lain-lain jelas-jelas telah mencoreng nilainilai dan marwah pendidikan itu sendiri. Bukan saja peserta didik yang dirugikan dalam hal ini, tetapi juga dunia pendidikan secara keseluruhan. Kehilangan motivasi belajar merupakan akibat nyata yang nampak pada diri siswa. Tidak adanya semangat belajar di sekolah menyebabkan siswa mengalihkan perhatian pada hal-hal lain yang lebih menarikperhatian mereka akibat lebih lanjut banyak siswa yang lebih banyak diluar sekolah saat jam belajar. Hal ini memicu perkelahian antar pelajar atau sering kita sebut tauran. Bagi sekolah tentunya ini selalu momok yang sangat menakutkan,bukan hanya kualitas pendidikan yang menurun, tapi juga animo masyarakat untuk mempercayakan pendidikan anaknya pada sekolah tersebut sangat berpengaruh buruk.
\end{abstract}

Kata Kunci: Kekerasan antarpelajar, Motivasi Belajar, Siswa Sekolah Dasar.

\section{PENDAHULUAN}

\section{Latar Belakang}

Pada usia Sekolah Dasar dari awal anak didik memasuki bangku sekolah sampai lulus dari jenjang tersebut biasanya mereka merasa bahwa teman merupakan segalanya bagi mereka, diusia ini mereka cenderung berkelompok sesuai jenis kelaminnya, merasa canggung jika berdekatan dengan lawan jenis,keluar dari zona lingkungan orangtua dan mulai mengenal zona sekolah dengan sesungguhnya.

Pada masa ini sekolah menjadi suatu hal yang rutin ia tunggu-tunggu setiap harinya, karna di sekolah ia dapat bertemu teman sebayanya dan mendapat nilai nilai yang bagus dari kerja kerasnya,dan rasa takut akan kesalahan yang ia lakukan sangat tinggi karena ia melihat orang tuanya dan gurunya ditambah anak tidak mau kehilangan teman karna kesalahannya. Namun akhir-akhir ini publik dikejutkan dengan meningkatnya tingkat kekerasan yang dilakukan anak terhadap teman sebayanya bahkan sampai mengakibatkan kematian, kemudian ada pula perilaku bullying yang sedang marak akhir-akhir ini di lansir dari KPAI, Selama tahun 2016 KPAI mencatat ada 1000 kasus kekerasan pada anak dan ketua bidang sosialisasi KPAI, Erlinda mengatakan, diantara 1000 kasus tersebut,ada 136 kasus kekerasan terhadap anak melalui medsos.

Baru-baru ini juga telah terjadi kekerasan antarpelajar Sekolah Dasar kelas 2 di Sukabumi Jawa Barat yang mengakibatkan meninggal dunia diduga setelah mengalami kekerasan dilingkungan 
sekolah pada selasa (8/8/2017) pagi. Keluarga kemudian membawa jenazah anak tersebut untuk menjalani autopsi di RSUD Sekarwangi Cibadak, setelah dilakukan autopsi dokter forensik menemukan sejumlah luka akibat kekerasan ditubuh korban yaitu luka lecet dipelipis korban, korban diketahui bertengkar dengan teman sekelas nya berinisial DI, dihalaman sekolahnya, Kecamatan Cicantayan, Kabupaten Sukabumi, Jawa barat. DI mengaku telah berkelahi dengan SR. (Keluarga Pelajar SD Tewas di Sukabumi Minta Pelaku di Proses Hukum, 2017, Liputan6.com, http://m.liputan6.com/news/read/3053018)

Maka dari itu, kasus kekerasan antar siswa akhir-akhir ini semakin meningkat dikhawatirkan dapatmempengaruhi motivasi belajar pada siswa. Karena apa yang siswa pikirkan dan siswa lakukan bukan lah perilaku yang menjurus pada prestasi disekolah, dan kebanggaan yang diakibatkan karna pelajaran itu dinomor dua kan oleh siswa karena mereka lebih mementingkan kebanggan karena hal lain yang mereka anggap keren dan sedang tren saat ini misalnya menurut mereka kesetiakawanan merupakan hal yang sangat penting meski dalam hal-hal yang negatif misal membela temannya dengan perkelahian, hal-hal ini lah yang mengakibatkan menurunnya motivasi belajar siswa ditambah peran media sosial dan teknologi yang digunakan anak-anak tiak terkendali dan tanpa pengawasan orangtua, juga kurangnya pendidikan moral dan agama dari orangtuanya. Hal ini merupakan salah satu yang mengakibatkan kekerasan yang dilakukan siswadan hal ini sangat berpengaruh besar terhadap motivasi belajar siswa yang kian menurun.

\section{Karakteristik Siswa Sekolah Dasar}

Pada usia siswa sekolah dasar, siswa sudah mulai memiliki kesanggupan menyesuaikan diri sendiri (egosentris) kepada sikap yang kooperatif (bekerjasama) atau sosiosentris (mau memperhatikan kepentingan orang lain).
Anak dapat berminat terhadap kegiatan Kegiatan teman sebayanya, Dan bertambah kuat keinginannya untuk diterima menjadi anggota kelompok (gang), Dia merasa tidak senang apabila tidak diterima dalam kelompoknya.

Emosi merupakan faktor dominan yang mempengaruhi tingkah laku individu,dalam hal ini termasuk pula perilaku belajar.Kemampuan mengontrol emosi diperoleh anak melalui peniruan dan latihan atau pembiasaan. Apabila anak dikembangkan dalam lingkungan keluarga yang suasana emosionalnya stability, maka perkembangan Emosi Anak cenderung stabil. Akan tetapi apabila kebiasaan orangtua dalam mengekspresikan emosinya kurang stabil Dan kurang kontrol, maka perkembangan emosi anak cenderung kurang stabil.emosi yang secara umum dialami pada tahap perkembangan usia sekolah ini adalah marah, takut, cemburu, iri hating, kasih sayang, rasa ingin tahu, dan kegembiraan. (Syamsu Yusuf, 2012: 180-181).

\section{Kasus Kekerasan Antar Pelajar}

Komisi Perlindungan Anak Indonesia (KPAI) menyatakan, kekerasan pada anak selalu meningkat setiap tahun.Hasil pemantauan KPAI dari 2011 sampai 2014, terjadi peningkatan yang sifnifikan. "Tahun 2011 terjadi 2178 kasus kekerasan, 2012 ada 3512 kasus, 2013 ada 4311 kasus, 2014 ada 5066 kasus," kata Wakil Ketua KPAI, Maria Advianti kepada Harian Terbit, Minggu (14/6/2015). (artikel Devit Setiawan: 2015)

Kekerasan anak di sekolah di berbagai daerah di Indonesia sudah memasuki tahap memprihatinkan.Cukup banyak siswa yang menganggap bahwa kekerasan yang dialami atau yang dilakukan sebagai tindakan wajar. Banyak guru dan orangtua siswa yang cenderung tidak mengadukan kekerasan di sekolah karena khawatir akan menjadi pihak yang disalahkan.

Dewan Pertimbangan Federasi Serikat Guru Indonesia (FSGI) Doni 
Koesema mengatakan, guru harus punya peran penting dalam menangani kasus kekerasan anak di sekolah.Mereka juga harus berani memberi sanksi tegas pada siswa yang melanggar atau melakukan tindak kekerasan maupun bullying.

"Guru tidak boleh takut memberi sanksi pada siswanya jika berbuat salah. Kalau ada 1 anak melakukan kekerasan atau bullying tidak diberi sanksi, maka besok akan ditiru banyak temannya," ujar Doni dalam diskusi bertema 'Stop Kekerasan dan Ciptakan Sekolah Ramah Anak' yang diselenggarakan Forum Musyawarah Guru Jakarta (FMGJ) di Jakarta, Sabtu (14/3/2015).

Diena ( 2017) mengatakan, permasalahan kekerasan berakar dari tindakan bullying. Bullying sendiri hanya bisa dilihat dalam perspektif korban. Karena tidak semua anak ketika diejek akan berdampak serius pada psikologisnya. Namun demikian, bullying tidak bisa dianggap enteng karena bisa berdampak pada tumbuh kembang anak.Bahkan bisa memicu tindak kekerasan, pengeroyokan, hingga pembunuhan.

Sementara aktivis Gerakan Nasional Anti-Bullying (Genab) Mardianto Janna mengatakan, bullying terjadi karena rasa saling menghormati antarteman, orangtua, guru mulai hilang.Ia mengajak kepada semua pihak baik guru, orangtua, pemerintah maupun masyarakat umum lebih sadar terhadap permasalahan kekerasan anak di sekolah ini.

\section{Motivasi Belajar}

Menurut Mc. Donald, yang dikutip Oemar Hamalik (2003:158) motivasi adalah perubahan energi dalam diri seseorang yang ditandai dengan timbulnya perasaan dan reaksi untuk mencapai tujuan. Dengan pengertian ini, dapat dikatakan bahwa motivasi adalah sesuatu yang kompleks.

Motivasi akan menyebabkan terjadinya suatu perubahan energi yang ada pada diri manusia, sehingga akan bergayut dengan persoalan gejala kejiwaan, perasaan dan juga emosi, untuk kemudian bertindak atau melakukan sesuatu.

Dalam A.M. Sardiman (2005:75) motivasi belajar dapat juga diartikan sebagai serangkaian usaha untuk menyediakan kondisi-kondisi tertentu, sehingga seseorang mau dan ingin melakukan sesuatu, dan bila ia tidak suka, maka akan berusaha untuk meniadakan atau mengelak perasaan tidak suka itu.

Menurut Siti Sumarni (2005), Thomas L. Good dan Jere B. Braphy (1986) mendefinisikan motivasi sebagai suatu energi penggerak dan pengarah, yang dapat memperkuat dan mendorong seseorang untuk bertingkah laku. Ini berarti perbuatan seseorang tergantung motivasi yang mendasarinya.

Motivasi adalah sesuatu yang dibutuhkan untuk melakukan aktivitas. Masih dalam artikel Siti Sumarni (2005), motivasi secara harafiah yaitu sebagai dorongan yang timbul pada diri seseorang secara sadar atau tidak sadar, untuk melakukan suatu tindakan dengan tujuan tertentu. Sedangkan secara psikologi, berarti usaha yang dapat menyebabkan seseorang atau kelompok orang tergerak melakukan sesuatu karena ingin mencapai tujuan yang dikehendakinya, atau mendapat kepuasan dengan perbuatannya (KBBI, 2001:756). 


\section{METODE PENELITIAN}

Metode penelitian ini adalah kualitatif bersifat interaktif, berlangsung dalam lingakaran yang tumpang tindih. Langkah-langkahnya disebut strategi pengumpulan dan analisis data, teknik yang digunakan fleksibel, tergantung pada strategi terdahulu yang digunakan dan data yang telah diperoleh. Milles dan Huberman (dalam Sangit) mengemukakan bahwa pendekatan dalam analisis data kualitatif terdiri dari reduksi data, display data, mengambil kesimpulan, dan verifikasi, yang dialakukan dalam bentuk interaktif dengan proses pengumpulan data sebagai suatu proses yang berlanjut, berulang, dan terus menerus hingga membentuk suatu siklus.

\section{Teknik Pengumpulan Data}

Data adalah bahan mentah yang perlu diolah sehingga menghasilkan informasi atau keterangan, yang menunjukkan fakta (Riduwan,2010). Teknik yang digunakan dalam mengumpulkan data penelitian ini adalah:

\section{Wawancara}

Wawancara adalah suatu cara pengumpulan data yang digunakan untuk memperoleh informasi langsung dari sumbernya. Ada beberapa faktor yang akan mempengaruhi arus informasi dalam wawancara, yaitu: pewawancara, responden, pedoman wawancara, dan situasi wawancara (Riduwan, 2010: 102).

\section{Observasi}

Observasi adalah pengamatan terhadap suatu objek yang diteliti baik secara langsung maupun tidak langsung untuk memperoleh data yang harus dikumpulkan dalam penelitian. Observasi kualitatif merupakan pengamatan langsung terhadap objek untuk untuk mengetahui keberadaan objek, situasi, konteks dan maknanya dalam upaya mengumpulkan data penelitian (Komariah, 2010: 105).

3. Studi Dokumentasi

Studi dokumentasi yaitu mengumpulkan dokumen data-data yang diperlukan dalam permasalahan penelitian lalu ditelaah secara intens sehingga dapat mendukung dan menambah kepercayaan dan pembuktian suatu kejadian (Komariah, 2010: 149).

\section{Lokasi penelitian}

Penelitian ini akan dilaksanakan di SDN Sukadamai Kota Bogor yang berjumlah 150 siswa.

\section{Tahapan dan Analisis data}

Metode pengumpulan dan analisis data penelitian kualitatif deskriptif bersifat interaktif, berlangsung dalam lingakaran yang tumpang tindih. Langkah-langkahnya disebut strategi pengumpulan dan analisis data, teknik yang digunakan fleksibel, tergantung pada strategi terdahulu yang digunakan dan data yang telah diperoleh (Sukmadinata, 2010:114). Milles dan Huberman (dalam Sangit, 2011) mengemukakan bahwa pendekatan dalam analisis data kualitatif terdiri dari reduksi data, display data, mengambil kesimpulan, dan verifikasi, yang dialakukan dalam bentuk interaktif dengan proses pengumpulan data sebagai suatu proses yang berlanjut, berulang, dan terus menerus hingga membentuk suatu siklus. Sebagaimana terlihat pada gambar 1.1 dibawah ini: 


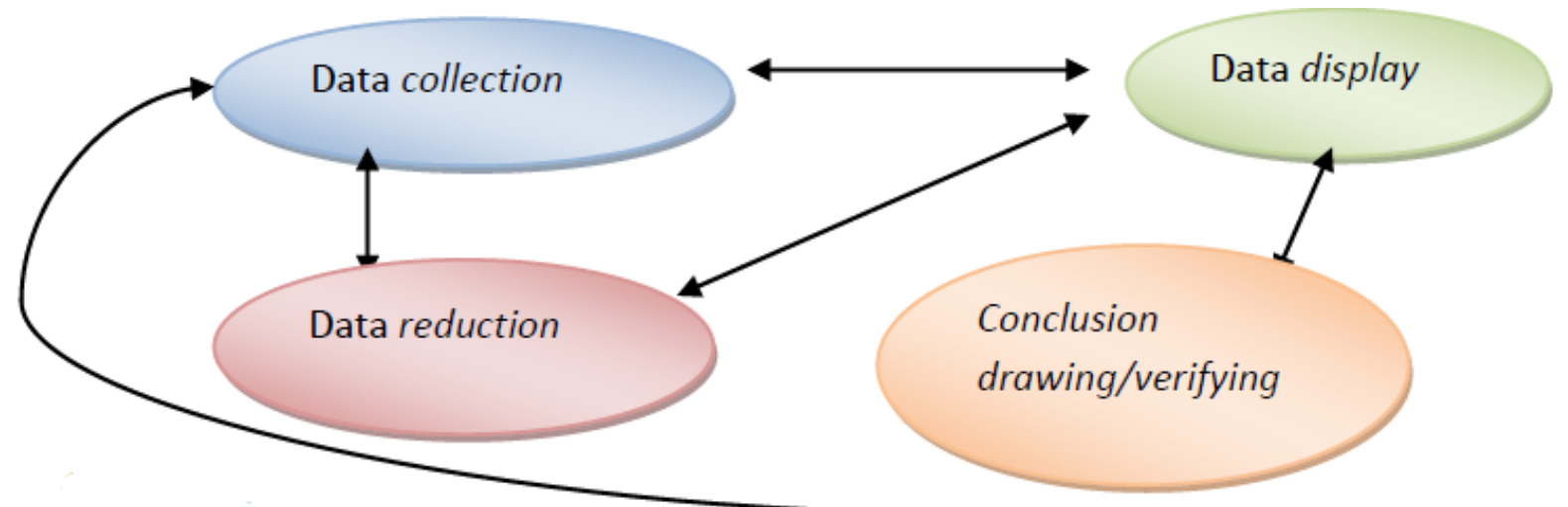

\section{Analisis data kualitatif \\ Sumber: Miles and Huberman}

Dari gambar diatas dapat dijelaskan secara rinci sebagai berikut ini:

\section{Reduksi data}

Mereduksi data dalam penelitian ini adalah sebagai proses merangkum data dari hasil observasi, wawancara, dan studi dokumentasi. Memilih, menyederhanakan, memilih hal-hal penting dan pokok yang dibutuhkan dalam kegiatan penelitian dilakukan secara terus menerus selama penelitian berlangsung sehingga peneliti mendapatkan data yang jelas.

2. Display data

Display data ini merupakan proses penyajian data, yaitu dilakukan setelah data terkumpul. Dengan disajikan maka peneliti akan mudah untuk membuat kesimpulan dan memahami data lebih jelas. Penyajian data dikumpulkan dari hasil wawancara, observasi dan studi dokumen dan akan mempermudah analisis data lebih lanjut.

\section{Verifikasi data}

Verifikasi adalah kegiatan menarik kesimpulan dari semua data-data yang diperoleh. Dari hasil reduksi dan display maka peneliti akan melakukan verifikasi menarik kesimpulan dari hasil penelitian yang telah dilakukannya.

\section{BIAYA DAN JADWAL KEGIATAN}

\begin{tabular}{|l|l|l|}
\hline No & Jenis Pengeluaran & Biaya (Rp) \\
\hline 1. & Peralatan penunjang & Rp. 3.500 .000 \\
\hline 2. & Bahan habis pakai & Rp. 4.000 .000 \\
\hline 3 & Perjalanan & Rp. 2.500 .000 \\
\hline 4 & Lain-lain: Administrasi,publikasi,seminar,laporan & Rp. 2.500 .000 \\
\hline & Jumlah & Rp. 12.500 .000 \\
\hline
\end{tabular}




\begin{tabular}{|c|c|c|c|c|c|c|}
\hline \multirow{2}{*}{ No } & \multirow{2}{*}{ Jenis Kegiatan } & \multicolumn{5}{|c|}{ Bulan } \\
\hline & & 1 & 2 & 3 & 4 & 5 \\
\hline 1 & Observasi & & & & & \\
\hline 2 & Studi Pendahuluan & & & & & \\
\hline 3 & $\begin{array}{l}\text { Pembuatan } \\
\text { Instrumen }\end{array}$ & & & & & \\
\hline 4 & $\begin{array}{l}\text { Perancangan } \\
\text { Perangkat } \\
\text { Pembelajaran }\end{array}$ & & & & & \\
\hline 5 & Uji Coba Media & & & & & \\
\hline 6 & $\begin{array}{l}\text { Pelaksanaan } \\
\text { Penelitian }\end{array}$ & & & & & \\
\hline 7 & Laporan & & & & & \\
\hline 8 & Seminar & & & & & \\
\hline
\end{tabular}

\section{KESIMPULAN}

\section{Tujuan}

Tujuan khusus penelitian ini adalah berusaha untuk menemukan informasi yang

terkait dengan:

1 Penyebab terjadi kekerasan antar siswa Sekolah Dasar

2 Langkah-langkah mengahadapi aksi kekerasan antar pelajar

3 Pengaruh kasus kekerasan terhadap motivasi belajar siswa dalam mengikuti kegiatan belajar mengajar

\section{Urgensi (Keutamaan Penelitian)}

Tingginya angka kekerasan yang terjadi pada tingkat sekolah dasar memberikan dampak negatif yang berujung pada menurunnya motivasi belajar siswa. Penelitian

ini sangat penting didasarkan kepada pertimbangan sebagai berikut:

1 Semakin maraknya kasus kekerasan antar pelajar yang terjadi di sekolah dan di luar sekolah
2 Kasus kekerasan sudah terjadi di kalangan usia anak-anak sekolah dasar

3 Terjadi kasus traumatis pada korban kekerasan yang mengakibatkan siswa malas dan takut ke sekolah 4 Kurangnya pendidikan moral dan agama disekolahnya

5 Minimnya pengawasan dari pihak keluarga, sekolah dan masyarakat

6 Kegiatan diluar sekolah yang kurang pengawasan dengan baik

\section{Temuan yang ditargetkan dan kontribusi terhadap ilmu pendidikan}

Temuan atau inovasi yang ditargetkan serta penerapannya dalam menunjang pembangunan dan pengembangan sosial humaniora atau Iptek-Sosbud:

1 Mendapatkan informasi mengenai dampak aksi kekerasan terhadap motivasi belajar siswa

2 Memperoleh solusi terhadap masalah kekerasan antar pelajar 
3 Membentuk karakter yang baik pada peserta didik melalui kegiatankegiatan tambahan di sekolah.

Luaran Penelitian

\begin{tabular}{|c|c|c|}
\hline No. & Jenis Luaran & Keterangan (bentuk) \\
\hline 1 & Artikel ilmiah & $\begin{array}{c}\text { Jurnal pendidikan dasar p-ISSN 2086- } \\
7433 \text { (cetak) e-ISNN 2549-5801 } \\
\text { (online) }\end{array}$ \\
\hline 2 & Buku Panduan & Siswa Anti Kekerasan \\
\hline
\end{tabular}

\section{Manfaat Penelitian}

Manfaat penelitian ini dapat diuraikan sebagai berikut:

1 Manfaat teoritis

1.1 Menambah wawasan mengenai dampak negatif dari perilaku

kekerasan dan pentingnya meningkatkan motivasi belajar siswa

\section{REFERENSI}

Davit Setyawan. 2014.KPAI : Kasus Bullying dan Pendidikan Karakter. Di unduh dari

http://www.kpai.go.id/berita/kpai-kasusbullying-dan-pendidikan-karakter

http://www.republika.co.id/berita/nasional/ umum/17/11/26/p00yyq330-kpai-
1.2 Menjadi masukan bagi pengelola sekolah untuk meningkatkan motivasi belajar

2 Manfaat praktis

2.1 Meningkatkan motivasi belajar siswa melalui kegiatan luar sekolah 2.2 Mengurangi tingkat kekerasan antar siswa pada sekolah tersebut

lemahnyapengawasan-sebabkanperkelahian-pelajar

Riset di

5http://news.liputan6.com/read/2191 106/survei-icrw-84-anak-indonesiaalamikekerasan-di-sd 